\title{
PROFIL PERENCANAAN KARIR MAHASISWA BIMBINGAN DAN KONSELING UNIVERSITAS MATHLAÚL ANWAR
}

\author{
Fadhila Malasari ${ }^{1}$, Mila Rosmila ${ }^{2}$ \\ Universitas Mathlaúl Anwar ${ }^{1,2}$ \\ fadhila.m.a@gmail.com ${ }^{1}$
}

\begin{abstract}
Article History: Received: 26/03/2021

Revised: 28/06/2021; Accepted: 02/07/2021 Published: $31 / 07 / 2021$.
\end{abstract}

How to cite:

Malasari, F \& Rosmila, M. (2021). Profil perencanaan karir mahasiswa Bimbingan dan Konseling Universitas Mathlaúl

Anwar. Jurnal Selaras: Kajian Bimbingan dan Konseling Serta Psikologi Pendidikan, Vol. 4(1), 09-16.

https://doi.org/10.33541/Jsvol2iss1pp1

This work is licensed under a

Creative Commons AttributionShareAlike 4.0 International License

\begin{abstract}
This study aims to reveal the level of career planning abilty of university students at the Guidance and Counseling Study Program Faculty of Teacher Training and Education, Mathla'ul Anwar Banten University. This research is a quantitative research with a descriptive method. The instrument used was the developed career planning ability with 63 statement items. The research subjects were all students of the Guidance and Counseling Study Program Faculty of Teacher Training and Education, Mathla'ul Anwar Banten University, totaling 30 people. The data analysis used in this research is descriptive statistics with percentage techniques. The results showed that $60 \%$ of students had very high career planning abilities, and $40 \%$ of students had career planning abilities in the medium category. The results of this study can be used by researchers to design programs that allow students to further develop their career planning abilities.
\end{abstract}

Keywords: career planning, university student

Abstrak: Penelitian ini bertujuan untuk mengungkap tingkat kemampuan perencanaan karir mahasiswa Prodi Bimbingan dan Konseling Fakultas Keguruan dan Ilmu Pendidikan Universitas Mathla'ul Anwar Banten. Penelitian ini merupakan penelitian kuantitatif dengan metode deskriptif. Instrumen yang digunakan adalah angket kemampuan perencanaan karir yang telah dikembangkan dengan 63 item pernyataan. Subjek penelitian adalah seluruh mahasiswa Bimbingan Konseling Fakultas Keguruan dan Ilmu Pendidikan Universitas Mathla'ul Anwar Banten yang berjumlah 30 orang. Analisis data yang digunakan dalam penelitian ini adalah statistik deskriptif dengan teknik persentase. Hasil penelitian menunjukkan $60 \%$ mahasiswa memiliki kemampuan perencanaan karir sangat tinggi, dan 40\% mahasiswa memilki kemampuan perencanaan karir pada kategori sedang. Hasil penelitian ini dapat digunakan peneliti untuk merancang program yang dapat mahasiswa mengembangkan kemampuan perencanaan karir mahasiswa lebih lanjut

Kata Kunci: perencanaan karir, mahasiswa

\section{PENDAHULUAN}

Masa remaja adalah masa peralihan dari usia kanak-kanak menuju usia dewasa. Masa remaja juga dikenal sebagai masa kritis, dimana sebagian dari mereka pada usia ini mengalami permasalahan dalam menghadapi perubahan-perubahan yang terjadi pada diri mereka. Perubahan-perubahan tak terduga ini membuat remaja mengalami kesulitan, sehingga membutuhkan bantuan orang lain dalam mengatasinya. Pada masa remaja, salah satu tugas perkembangan pada usia remaja adalah mempersiapkan karir, khususnya memilih serta mempersiapkan diri ke arah suatu pekerjaan (Hurlock, 2004). Karir, menjadi salah satu 
permasalahan yang sering dihadapi para remaja dalam menyelesaikan tugas perkembangannya. Hal ini dapat terlihat dari banyaknya siswa SMA yang bingung menentukan pilihan studi lanjutnya di bangku universitas, dan juga merasa salah memilih jurusan.

Yusuf dan Nurihsan (2011) mengatakan bahwa memilih dan mempersiapkan karir merupakan salah satu tugas perkembangan yang harus ditempuh pada usia remaja. Yusuf (2014) juga menjelaskan bahwa pada masa remaja, individu dituntut untuk dapat memilih suatu pekerjaan yang sesuai dengan kemampuannya dan mempersiapkan diri dengan cara berusaha memperoleh pengetahuan dan keterampilan untuk memasuki pekerjaan tersebut. Ukuran dan kekuatan fisik pada usia remja juga sudah lebih matang, sehingga mempermudah remaja dalam mempelajari keterampilan atau keahlian yang dituntut oleh suatu pekerjaan tertentu. Super (Iffah \& Pratiwi, 2013) mengemukakan bahwa tugas-tugas perkembangan karir remaja adalah mengembangkan konsep diri yang realistik, belajar lebih banyak tentang kesempatan yang luas, mulai memilih jurusan di perguruan tinggi, melakukan pengecekan pilihan-pilihan perkehaan secara tentatif, dan mengurangi waktu untuk kegiatan kesenangan/hobi.

Teori diatas menunjukkan betapa pentingnya perencanaan karir pada remaja, sebab perencanaan karir akan memberikan efek jangka panjang pada kehidupan seseorang. Karir bukan hanya berbicara tentang pekerjaan semata, melainkan proses berkesinambungan untuk meraih suatu capaian karir. Perencanaan karir ini merupakan salah satu aspek penting dalam pencarian identitas pada remaja.

Perencanaan karir dapat didefinisikan sebagai proses teratur yang sengaja dirancang agar individu menjadi sadar akan atribut-atribut yang berkenaan dengan karir personal (personal career related) dan serangkaian panjang tahap-tahap yang menyumbang pada pemenuhan karir dalam mencapai karir individu itu sendiri. Selain itu, Sutrino (2013) menejelaskan bahwa perencanaan karir merupakan proses individu memilih sasaran karir dan jalur menuju sasaran tersebut agar tidak salah dalam pemilihan karir dan jelas arah karirnya. Perencanaan karir dapat juga dikatakan sebagai proses yang dilalui seseorang sebelum melakukan pemilihan karir untuk mencapai karir tertentu (Liza \& Rusandi, 2016).

Beberapa penelitian dan temuan menunjukkan bahwa sebagian besar remaja masih kesulitan dalam menentukan perencanaan karir. Berdasarkan hal tersebut, penulis tertarik untuk mencari informasi lebih konkret bagaimana perencanaan karir bagi mahasiswa. Hal ini menjadi menarik karena mereka telah memilih program studi tertentu sebagai studi lanjutan. Individu dalam tahap ini berperan sebagai mahasiswa yang sudah terjun ke dalam rumpun ilmu yang sudah menjurus, idealnya perencanaan karir sudah tergambar secara utuh ketika mereka selesai menempuh pendidikan Sarjana. 
Seiring meningkatnya minat pelajar sekolah menengah untuk melanjutkan studi ke perguruan tinggi, jumlah sarjana yang diluluskan perguruan tinggi setiap tahunnya selalu mengalami peningkatan. Hal ini berdampak positif pada jumlah lulusan universitas, yang setiap tahunnya semakin banyak mencetak para sarjana. Akan tetapi, persentase lulusan sarjana yang langsung mendapatkan pekerjaan tidak sebanding dengan jumlah lulusan itu sendiri. Hal ini menjadi polemik bagi pemerintah, karena bertambahnya jumlah pengangguran yang sebagiannya adalah individu dengan gelar sarjana. Terbukti dengan melihat data yang dipublikasikan dipublikasikan oleh Kementerian Tenaga Kerja, menyatakan jumlah pengangguran sarjana hingga Februari 2013 mencapai 360.000 orang atau 5,04 persen dari total pengangguran yaitu 7,17 juta orang (Ibda, 2013).

Setelah ditelusuri, dapat disimpulkan bahwa salah satu faktor yang menyebabkan para sarjana ini belum mendapat pekerjaan adalah dikarenakan mereka masih bingung dengan perencanaan karirnya. Ketika masih menjadi menjadi mahasiswa, mereka merasa bingung tentang pekerjaan apa yang akan mereka tekuni kelak, dan tidak merencanakan semua itu dengan baik. Hal ini menunjukkan bahwa mereka belum memiliki perencanaan karir yang baik. Padahal, Paolillo et al mengatakan perencanaan karir merupakan hal yang sangat penting untuk mencapai sukses (dalam Rasmini, 2007). Sejalan dengan yang diungkapkan oleh Berry (dalam Harris dan Djamhuri, 2001), bahwa perencanaan karir merupakan suatu hal yang sangat penting untuk mencapai kesuksesan dalam karir.

Penelitian yang dilakukan Lestari \& Rahardjo (2013) menunjukkan bahwa para sarjana yang baru lulus tidak mempertimbangkan minat, kemampuan dan kepribadiannya dalam memilih suatu pekerjaan secara serius. Mereka memilih untuk berkerja dalam bidang tertentu karena merasa cemas dan khawatir jika terlalu lama menganggur, merasa malu pada lingkungan sekitarnya jika belum bekerja, dan adanya tuntutan dari orangtua. Hal ini sejalan dengan hasil penelitian yang dilakukan Kasih dan Suganda (Hendayani dan Abdullah, 2018) yang menunjukkan bahwa 91\% kalangan dunia usaha beranggapan lulusan perguruan tinggi tidak siap pakai selepas kuliah.

Perencanaan karir seseorang memiliki kaitan erat dengan tugas perkembangan yang dialami individu tersebut. Ginzberg, et al (dalam Ozora, Suharti, Sirine, 2016) mengemukakan bahwa perkembangan karir berdasarkan usia individu terbagi ke dalam tiga tahap, yakni: tahap fantasi (0 -11 tahun, masa Sekolah Dasar), tahap tentatif (12 -18 tahun, masa Sekolah Menengah), dan tahap realistis (19-25 tahun, masa Perguruan Tinggi). Dalam hal ini, sarjana masuk ke dalam tahapan realistis, dimana mereka seharusnya sudah mengenal secara lebih baik minat-minat, kemampuan, dan nilai-nilai yang ingin dikejar. Para sarjana juga selayaknya 
sudah lebih memahami dan mengkategorisasi berbagai bidang pekerjaan dengan segala konsekuensi dan tuntutannya masing-masing.

Sesuai dengan pernyataan tersebut, penelitian ini berfokus pada tahap realistis, di mana individu tersebut telah berada pada jenjang perguruan tinggi. Pemilihan dan persiapan diri untuk menjalankan suatu pekerjaan atau karir merupakan salah satu tugas penting dalam tahap perkembangannya. Mahasiswa sebaiknya sudah mempunyai kejelasan arah pilihan bidang minat karir yang tinggi sedini mungkin sejak semester awal, sehingga mereka akan terbantu dalam menentukan langkah-langkah yang diambil dalam mencapai kesuksesan dalam berkarir serta dapat mengembangkan keterampilan dan keahlian yang dibutuhkan dalam dunia kerja.

\section{METODE PENELITIAN}

Metode penelitian yang digunakan dalam penelitian ini adalah deskriptif kuantitatif. Penelitian dengan metode ini bertujuan menggambarkan dan menjelaskan data yang bersifat aktual, lalu melakukan analisis dari hasil yang diperoleh, sehingga data tersebut dapat diinterpretasikan secara jelas dan konkrit, sehingga variabel yang diteliti dapat diinterpretasikan dengan jelas dan konkrit.

Subjek penelitian ini adalah seluruh mahasiswa Bimbingan dan Konseling Universitas Mathlaúl Anwar yang terdiri dari tiga angkatan, yakni angkatan 2017, 2018, dan 2019. Penelitian ini menggunakan instrumen yang telah dikembangkan sebelumnya oleh peneliti, yaitu angket perencanaan karir dengan 63 butir pernyataan. Hasil penelitian kemudian dikategorisasikan menjadi tiga kategori, yaitu tinggi, sedang, dan rendah. Analisis data yang digunakan pada penelitian ini adalah statistik deskriptif dengan teknik persentase. Hal ini dilakukan untuk mendeskripsikan atau memberi gambaran terhadap obyek yang diteliti melalui populasi yang dipilih.

\section{HASIL DAN PEMBAHASAN}

Kemampuan perencanaan karir mahasiswa diukur dengan menggunakan instrumen perencanaan karir yang telah dirancang oleh peneliti. Instrumen yang digunakan adalah kuesioner yang telah disusun sebelumnya dengan tujuan memperoleh gambaran kemampuan perencanaan karir mahasiswa Bimbingan dan Konseling Universitas Mathlaúl Anwar. Kuesioner perencanaan karir ini dilengkapi dengan 5 alternatif respon pernyataan, yaitu Sangat Sesuai (SS), Sesuai (S), Cukup Sesuai (CS), Tidak Sesuai (TS), dan Sangat Tidak Sesuai (STS).

Perencanaan karir sejatinya adalah hal yang esensial dan harus dimiliki oleh setiap individu, terutama remaja akhir menuju usia dewasa. Kemampuan merencanakan karir dengan 
baik akan mereduksi kebimbangan dan ketegangan individu dalam mencari informasi karir dan pengambilan keputusan karir yang diinginkan.

Berdasarkan penelitian yang telah dilakukan, tampak bahwa sebagian besar mahasiswa BK FKIP UNMA Banten telah memiliki kemampuan perencanaan karir dalam kategori tinggi. Hal ini dapat dilhat dari tabel dibawah ini

Tabel 1.

Profil Perencanaan Karir Mahasiswa Prodi BK UNMA

\begin{tabular}{ccc}
\hline Kategori & Jumlah & Persentase \\
\hline Tinggi & 18 & $60 \%$ \\
\hline Sedang & 20 & $40 \%$ \\
\hline Rendah & - & $\mathrm{F}$ \\
\hline
\end{tabular}

Tabel tersebut menunjukkan bahwa 60 persen mahasiswa memiliki kemampuan perencanaan karir pada kategori tinggi, 40 persen berada pada kategori sedang, dan tidak seorangpun berada dalam kategori rendah. Skor tertinggi yang diperoleh mahasiswa adalah 266 dari skor maksimal 315 dan skor terendah adalah 206 dari skor minimal 63. Jumlah tersebut menunjukkan bahwa rata-rata mahasiswa bimbingan dan konseling FKIP UNMA Banten telah memiliki kemampuan perencanaan karir yang baik, dimana mereka telah berusaha memahami potensi yang ada dalam dirinya, memahami lingkungannya, pilihan-pilihan karir yang sesuai dengan dirinya, selanjutnya mempersiapkan karir yang akan dijalani nantinya sehingga karirnya akan terarah.

Data tersebut juga menunjukkan bahwa mahasiswa BK UNMA dapat memiliki kemampuan yang baik dalam pengenalan diri, meliputi pemahaman akan minat, bakat, kemampuan, cita-cita dan juga kepribadiannya. Mereka juga telah melakukan upaya pengenalan lingkungan tempat pendidikan lanjutannya serta bidang pekerjaan yang mereka inginkan. Selain itu, mereka juga telah memperhitungkan peluang dengan baik, memiliki keteguhan akan tujuan pendidikan lanjutan serta bidang pekerjaan, mengeksplorasi informasi dengan baik, menyesuaikan pilihan pendidikan lanjutan dan bidang pekerjaan dengan bakat yang dimiliki, dan menunjukkan upaya dalam pencapaian cita-cita.

Pada penelitian ini, perencanaan karir didefinisikan sebagai respon mahasiswa dalam menyikapi pernyataan-pernyataan tertulis tentang kemampuan perencanaan karir yang teridiri dari tiga aspek berikut: 1) aspek pengetahuan dengan indikator: pemahaman diri, pengenalan lingkungan pendidikan lanjutan dan pekerjaan, pertimbangan peluang, 2) aspek sikap dengan indikator: peneguhan tujuan, pengeksplorasian sumber informasi, dan aspek 3) keterampilan 
dengan indikator: penyesuaian pilihan, dan pencapaian cita-cita. Pemahaman diri pada angket ini dimaknai sebagai kemampuan mahasiswa dalam mengenali dirinya (kebiasaan, minat, kemampuan, dan cita-cita). Pengenalan lingkungan pendidikan lanjutan dan pekerjaan, artinya kemampuan mahasiswa dalam memahami persyaratan yang diperlukan untuk memasuki pendidikan lanjutan dan bidang pekerjaan yang diinginkan. Pertimbangan peluang, artinya kemampuan mahasiswa dalam mengetahui prospek pilihan pendidikan lanjutan dan pekerjaan. Peneguhan tujuan, artinya kemampuan mahasiswa dalam meyakini pilihan pendidikan lanjutan dan bidang pekerjaan. Pengeksplorasian sumber informasi, artinya kemampuan mahasiswa dalam mengeksplorasi sumber informasi yang menunjang pilihan pendidikan lanjutan dan bidang pekerjaan. Penyesuaian pilihan, artinya kemampuan mahasiswa dalam menyesuaikan bakat dengan minat pilihan pendidikan lanjutan dan bidang pekerjaan. Pencapaian cita-cita, artinya kemampuan mahasiswa dalam menunjukkan cara-cara yang nyata dalam mencapai pendidikan lanjutan dan bidang pekerjaan yang diminati.

Berdasarkan pengertian tersebut maka tampak bahwa sebagian besar mahasiswa telah memahami dirinya, mengetahui bakat dan minat yang ada didirinya, mengetahui lingkungan kampus saat ini, dan mengetahui pekerjaan dan karir kedepannya yang kira-kira dapat mereka lakoni. Atmaja (2016) mengatakan bahwa perencanaan karir adalah perencanaan yang fokus pada pekerjaan dan pengidentifikasian jalan karir yang memberikan kemajuan yang logis atas orangorang diantara pekerjaan dalam organisasi.

Rata-rata mahasiswa FKIP Banten sudah mampu mempertimbangkan peluang yang berkaitan dengan karir, merasa yakin dengan cita-cita, pendidikan saat ini dan pekerjaan. Mahasiswa yang telah memiliki sikap ini, sebagian besar memiliki semangat dan niat yang kuat dalam mencari informasi yang berkaitan dengan pilihan pendidikan lanjutan dan pekerjaan yang dicita-citakan. Hanya beberapa orang peserta didik yang masih ragu-ragu akan cita-citanya dan tidak terlalu antusias dalam mengeksplorasi sumber informasi yang berkaitan dengan cita-cita pendidikan lanjutan dan pekerjaan yang ia inginkan. Hampir seluruh mahasiswa memahami pentingnya menyesuaikan kemampuan diri dengan pilihan pendidikan lanjutan dan pekerjaan. Mereka juga telah menunjukkan cara nyata dalam mencapai pendidikan lanjutan dan pekerjaan, yang ditunjukkan dengan keikutsertaan mereka dalam organisasi dan lembaga-lembaga yang menunjang pilihan karir dan sesuai program studi mereka saat ini. Hal tersebut dapat dilihat melalui diagram kemampuan perencanaan karir per aspek berikut ini: 


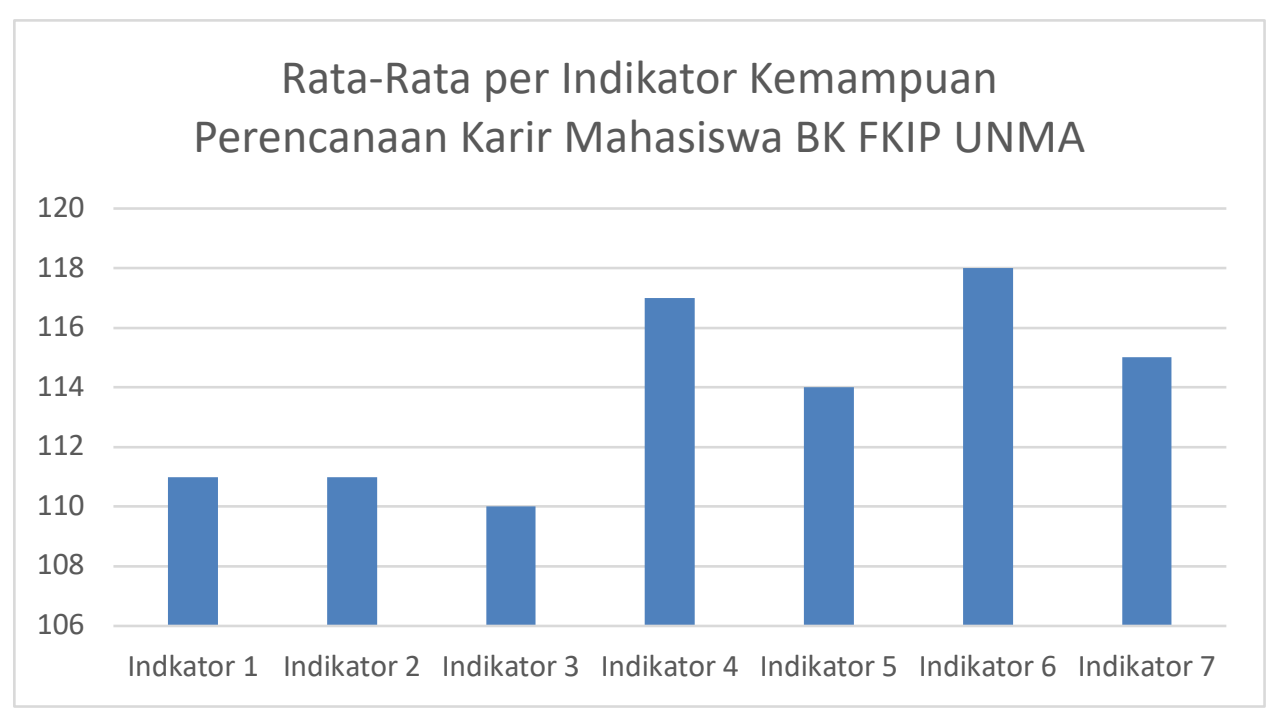

Grafik 1. Profil Kemampuan Perencanaan Karir Mahasiswa BK UNMA per Indiator

Suherman (2013) mengatakan bahwa perolehan skor kemampuan perencanaan karir pada mahasiswa ini dapat dipengaruhi oleh beberapa hal, diantaranya: kemampuan (abilities), minat (interest) dan prestasi (achievement). Kemampuan dalam hal ini adalah kepercayaan diri terkait dengan bakat yang menonjol disuatu bidang usaha kognitif, bidang keterampilan, atau bidang kesenian. Minat, merupakan kecenderungan yang agak menetap kepada seseorang untuk merasa tertarik pada suatu bidang tertentu dan merasa senang bergaul atau bergabung dalam berbagai kegiatan yang berkaitan dengan bidang tersebut. Sedangkan prestasi merupakan suatu hasil belajar (prestasi belajar), yang didapatkan dari suatu kemampuan individu yang didapatkan siswa dari usaha belajar.

\section{KESIMPULAN DAN SARAN}

Temuan pada penelitian ini adalah bahwa dari 30 orang mahasiswa program studi Bimbingan dan Konseling Fakultas Keguruan dan Ilmu Pendidikan Universitas Mathla'ul Anwar Angkatan, 60 persennya atau sebanyak 18 orang merupakan pribadi yang memiliki perencanaan karir pada kategori tinggi. Sebanyak $40 \%$ atau sebanyak 12 orang merupakan pribadi yang memiliki kemampuan perencanaan karir pada kategori rendah, dan tidak satupun yang berada dalam kategori rendah. Hal ini menunjukkan bahwa mereka telah benar-benar memahami potensi diri dan lingkungannya. Sebaiknya, mahasiswa senantiasa menjaga dan meningkatkan lagi perencanaan karirnya menjadi ketetapan karir dengan cara mengikuti berbagai pelatihan yang sesuai dengan program studi dan rencana karir ke depan 


\section{DAFTAR PUSTAKA}

Hendayani, N., \& Abdullah, S. M. (2018). Dukungan teman sebaya dan kematangan karier mahasiswa tingkat akhir. Jurnal Ilmiah Psikologi Terapan, Vol.6(1), 28-40. https://doi.org/10.22219/jipt.v6i1.5189

Hurlock, E. B. 2004. Psikologi Perkembangan Suatu Pendekatan Sepanjang Rentang Kehidupan. Edisi Kelima (Terjemahan Instiwidayanti dan Soedjarwo). Jakarta: Erlangga.

Ibda, H. (2013). Mencari Solusi Pengangguran Terdidik. http://www.kompi.org/2013/12/mencari-solusi-pengangguranterdidik. html

Iffah, H. M., \& Pratiwi, I. (2013). Layanan informasi Karir Melalui Media Permainan Monopoli utnuk meningkatkan Kemantapan Pengambilan Keputusan Studi Lanjut Siswa Kelas XII IPA-2 SMA N 1 Menganti. Jurnal BK UNESA. Vol. 03(01), 183 - 190.

Lestari, T. N., \& Rahardjo, P. (2013). Hubungan antara kecerdasan emosional dengan kematangan karir pada mahasiswa universitas muhammadiyah purwokerto yang sedang menempuh skripsi. Psycho Idea, Vol.11(2), 1-9. http://dx.doi.org/10.30595/psychoidea.v11i2.508

Liza, L. O., \& Rusandi, M. A. (2016). Pengaruh Layanan Informasi Tentang Studi Lanjut Terhadap Perencanaan Karir Siswa Kelas XI IPA SMA Negeri 1 Pekanbaru Tahun Ajaran 2013/2014. Jurnal Bimbingan Konseling Indonesia, 1(1), 14-17.

Ozora, D., Suharti, L., \& Sirine, H. (2016). Potret perencanaan karir mahasiswa (Studi terhadap mahasiswa di sebuah perguruan tinggi di Jawa Tengah. Seminar Nasional Multi Disiplin Ilmu \& Call For Paper Unisbank (SENDI_U), 623-632.

Rasmini, N. K. (2007). Faktor-faktor yang berpengaruh pada Keputusan Pemilihan Profesi Akuntan Publik dan Non Akuntan Publik pada mahasiswa Akuntansi di Bali. Buletin Studi Ekonomi, Vol. 12(3), 351-366.

Suherman, U. (2013). Bimbingan dan Konseling Karir: Sepanjang Rentang Kehidupan. Bandung: Rizqi Press.

Sutrino, B. (2013). Perencanaan Karir Siswa SMK (Sebuah Model Berbasis Pengembangan SoftSkill). Jurnal Varidika: Kajian Penelitian Pendidikan, 25(1), 1-14.

Yusuf, S., \& Nurihsan, J. (2011). Landasan Bimbingan dan Konseling. Bandung: Rosda.

Yusuf, S.L.N. (2014). Psikologi Perkembangan Anak dan Remaja. Bandung: Rosdakarya. 